\title{
European contract law: the way forward
}

\author{
Angelika Fuchs
}

Published online: 9 February 2011

(C) ERA 2011

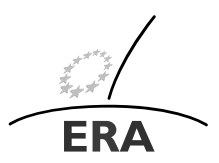

EUROPÄISCHE RECHTSAKADEMIE ACADEMY OF EUROPEAN LAW ACADEMIE DE DROIT EUROPEEN ACCADEMIA DI DIRITTO EUROPEO

For several years, ERA has been serving as a platform for discussion on recent developments in European contract law and the drafting of a Common Frame of Reference (CFR) which has been described as the "most important project in the area of civil justice in Europe" by Klaus-Heiner Lehne MEP. A major step forward has been announced for autumn 2011 when the European Commission will propose a legal instrument on European contract law as part of the effort to strengthen citizens' rights. ${ }^{1}$

\section{Background}

The history of drafting a European Contract Law goes back to the 1980s when on the one hand academic groups like the Lando Commission were created and on the other the European Parliament adopted several resolutions in which it called for the harmonisation of private law within the EC in order to complete the internal market. ${ }^{2}$ The initial step for the improvement of the existing EC consumer and contract law was the Commission communication on European Contract Law of $2001 ;^{3}$ and the

\footnotetext{
${ }^{1}$ In this context, the Polish Ministry of Justice, in the framework of the Polish Presidency of the Council of the EU and in cooperation with ERA, will organise a conference on European Contract Law in Warsaw on 9-10 November 2011.

${ }^{2}$ Starting with Resolution A2-157/89, OJ C 158, 26 June 1989.

${ }^{3} \operatorname{COM}(2001) 398$ final of 11 July 2001.
}

Dr. A. Fuchs $(\bowtie)$

Head of Section, Academy of European Law, Metzer Allee 4, 54295 Trier, Germany

e-mail: afuchs@era.int 
basis for the so-called Common Frame of Reference was laid down by the Commission's Action Plan in 2003. ${ }^{4}$ The future CFR was described in more detail in the subsequent Communication, ${ }^{5}$ which proposed that the CFR should provide fundamental principles of contract law, definitions of the main relevant abstract legal terms and model rules of contract law-its main purpose being to serve as a legislators' toolbox.

In May 2005, the Joint Network on European Private Law was established under the European Commission's sixth research framework programme. It fulfilled its aim with the delivery of a proposal for a CFR: in December 2008, the European Commission received the final version of the DCFR which was published in six volumes in 2009. ${ }^{6}$ It contains model rules, principles and definitions. "Model rules" bring together rules derived from the legal systems of the Member States and EU law; they are thoroughly explained by comments and notes. "Principles" explain the main underlying value judgments and "definitions" are added to define terms against the background of 30 jurisdictions.

On 5 June 2009, the Justice and Home Affairs Council adopted guidelines on the setting up of a CFR for European Contract Law. ${ }^{7}$ The Council confirmed that the CFR would set out common fundamental principles of contract law, definitions and model rules. The model rules should be general so that they can apply to all contracts. There was no decision on the form; however, the CFR should be suitable to serve as a common source of inspiration or reference in the European legislative process. In the Stockholm Programme for $2010-2014,{ }^{8}$ the European Council reaffirmed that the CFR should be a non-binding set of fundamental principles, definitions and model rules to be used in the lawmaking process and invited the Commission to submit a proposal for a CFR. It did not refer to the optional instrument briefly mentioned in the underlying Commission Communication. ${ }^{9}$

While the Council has been hesitant to take a strong position on this issue, the European Parliament has clearly marked the way forward: in its resolution on the Stockholm Programme ${ }^{10}$ the Parliament emphasised that "the political CFR should result in an optional and directly applicable instrument enabling parties to a contract inter alia companies and consumers, freely to choose European Contract Law as the law governing their transactions." This approach was then followed by the Commission in two landmark Communications. The Europe 2020 strategy for smart, sustainable and

\footnotetext{
${ }^{4}$ OJ C 63 of 15 March 2003.

${ }^{5} \operatorname{COM}(2004) 651$ of 11 October 2004; followed by $\operatorname{COM(2005)} 456$ final of 23 September 2005 and $\operatorname{COM}(2007) 447$ final of 25 July 207.

6 von Bar/Clive [1].

${ }^{7} 2946$ th Justice and Home Affairs Council meeting.

${ }^{8}$ OJ C $115 / 1$ of 4 May 2010, p. 16.

${ }^{9} \mathrm{COM}(2009) 262$ final of 10 June 2009, p. 13/14: "consideration could be given to an optional, specifically European system of rules open to companies (a 'twenty-eighth' system). This system would encourage the development of intra-Community trade and establish a single, directly applicable legal framework." Please note that according to this Communication, the optional instrument should be available only for companies and not for consumers.

${ }^{10}$ Resolution of 25 November 2009, P7_TA(2009)0090.
} 
inclusive growth recognises the need to make it easier and less costly for businesses and consumers to conclude contracts with partners in other EU countries, inter alia, by making progress towards an optional European Contract Law. ${ }^{11}$ The creation of such an instrument is also one of the key actions in the Commission's Digital Agenda for Europe. ${ }^{12}$

A new dimension to the whole project was given by Viviane Reding, VicePresident of the Commission responsible for Justice, Fundamental Rights and Citizenship, who declared at the hearing before the European Parliament that the CFR is "the embryo for a European Civil Code." 13

On 1 July 2010, a Green Paper with seven options for progress towards a European Contract Law was published. ${ }^{14}$ The options range from: online publication of the CFR, an official "toolbox" for the legislator, a Commission Recommendation, an optional instrument, a Directive or Regulation establishing a European Contract Law or a European Civil Code. Already before the end of the consultation period on 31 January 2011, it seemed obvious to some observers that the Commission favours the fourth option, i.e. a Regulation setting up an optional instrument which could be conceived as a 28 th legal regime in the EU. ${ }^{15}$

In parallel to the consultation, the Commission appointed an Expert Group in April $2010^{16}$ and Professor Christian von Bar and Professor Bénédicte Fauvarque-Cosson were appointed special advisors to Vice-President Reding. The group should help the Commission to select those parts of the DCFR which are of relevance for contract law, and restructure, revise and supplement the selected contents. The expert group will deliver the results of its work in spring 2011. Their draft will follow the life cycle of a contract, from pre-contractual duties and the formation of contract to remedies for the breach of a contract and the consequences of termination. Against this background, the Commission will then propose a legal instrument on European Contract Law in autumn 2011.

\section{From the DCFR to the optional instrument}

According to Vice-President Reding, divergent rules on contracts make life difficult for small and medium-sized enterprises trying to enter new markets within the EU and frustrate the efforts of consumers attempting to buy cross-border in the internal market. Progress towards an optional instrument could help resolve these problems. The so-called "blue button" has become a symbol for the future contract law: ${ }^{17}$ the trader,

\footnotetext{
${ }^{11} \operatorname{COM}(2010) 2020$ final of 3 March 2010, p. 21.

${ }^{12} \mathrm{COM}(2010) 245$ final/2 of 26 August 2010: "Propose by 2012 an optional contract law instrument complementing the Consumer Rights Directive to overcome the fragmentation of contract law, in particular as regards the online environment."

${ }^{13}$ Hearing of Viviane Reding, Commissioner-designate, 12 January 2010.

${ }^{14}$ COM(2010) 348 final of 1 July 2010.

${ }^{15}$ Tonner [6], pp. 767-768; Rösler [4], p. 1; Herresthal [2], p. 7.

${ }^{16}$ OJ L $105 / 109$ of 27 April 2010.

${ }^{17}$ Schulte-Nölke [5], pp. 131-142.
} 
for instance in an e-shop, could display the blue European flag as an icon which says "Sale under EU law". The client has the choice: if he or she clicks on the blue button, the optional instrument will become the applicable law for the transaction.

However, not everyone agrees with this analysis: criticism comes from different sides, arguing that a 28th system makes business in Europe even more complicated ${ }^{18}$ and the outcome of lawsuits unpredictable ${ }^{19}$ others are waiting for a proposal on the contents of the optional instrument. ${ }^{20}$ Consumer organisations, for instance, which have always favoured a minimum harmonisation by European directives, leaving room for the Member States to provide a higher standard of consumer protection, are afraid that the optional instrument will not give sufficient protection to the consumer.

The optional instrument provides - in the field of contract law-a completely different approach from the European legislator. ${ }^{21}$ Until now, private law has been harmonised by way of directives, mainly in the field of consumer law. These harmonisation efforts have been limited to certain fields of law. In contrast, the optional instrument provides for a single set of rules for the whole contract. It does not replace national contract law but gives an alternative to the contracting parties. They can choose whether to apply a national law or the optional instrument. Consequently, the optional instrument has no direct effect on national law. Further arguments in favour include the principle of proportionality (Art. 5 TEU). If the divergences between national contract laws constitute a barrier to the completion of the internal market, then the optional instrument will be the gentlest measure to overcome this difficulty. It remains to be seen whether it will prove to be effective in speeding up the further development of the internal market. This will depend to a large extent on its contents and the level of consumer protection provided for. The decision about the acceptance of the optional instrument will in any case be left to the market.

In drafting the optional instrument, a wide range of decisions must be taken. In this context, only three problems will be briefly mentioned.

First, it has to be decided whether the optional instrument will be the 28th (or more precisely the $31 \mathrm{st}$ ) regime or the 2 nd regime. If it were construed as a 28 th regime, it would be up to private international law (Art. 3 Rome I Regulation) to decide whether parties have chosen the optional instrument. The concept of a 2 nd regime is superior compared to that of a 28th regime. If the optional instrument were construed as a 2 nd regime, it would, like for instance the Convention on the International Sale of Goods (CISG), be part of the legal order of each Member State and could be qualified as an additional set of domestic rules. For the scope of application it was suggested to combine a rule of direct applicability (i.e. it would apply as uniform law) with a rule

\footnotetext{
${ }^{18}$ Schmitt/Balthasar, Pläne für ein europäisches Vertragsrecht haben erhebliche Mängel, FAZ 11 August 2010 .

${ }^{19}$ Lord Jonathan Mance [3], pp. 457-462.

${ }^{20}$ Tonner [6], pp. 767-771.

${ }^{21}$ Models might be the Community trade mark, the European Cooperative Society (SCE) and the European Company (SE), implemented in addition to national law systems.
} 
of indirect applicability (i.e. it would apply when private international law rules point to its application). ${ }^{22}$

Secondly, the personal scope of application needs to be defined. Should it cover both $\mathrm{B} 2 \mathrm{C}$ and $\mathrm{B} 2 \mathrm{~B}$ contracts? The drafters of the DCFR are clearly in favour of one optional instrument which covers both general contract law and consumer protection law. As the barriers for consumer cross-border trade are currently high, there is a special need for introducing an optional instrument in B2C-relationships. The "blue button" is not limited to consumer transactions. Having talked about small and medium-sized enterprises trying to enter new markets within the EU, there is certainly a need for an optional instrument in B2B-transactions.

Thirdly, concerning the scope of the instrument, the major question is whether parties can choose the optional instrument only in cross-border situations or whether they should be allowed to choose it in a purely domestic context. Recent regulations establishing the European Payment Order ${ }^{23}$ and the Small Claims Procedure ${ }^{24}$ are limited to cross-border situations. For the optional instrument, it would be preferable if it were not limited to cross-border contracts. ${ }^{25}$. A consumer who is looking on the Internet for a good deal should be in the position to press the "blue button" irrespective of whether the seller has its seat in the same or in another Member State. Only then will the parties be convinced that the optional instrument is not another foreign law, but part of their own legal system. In the long run, the distinction between purely domestic and cross-border business might then even gradually disappear.

\section{References}

1. Bar, C. von/Clive, E. (eds.): Principles, Definitions and Model Rules of European Private Law (2009)

2. Herresthal, C.: Ein europäisches Vertragsrecht als Optionales Instrument, EuZW (2011)

3. Mance, L.J.: The Common Frame of Reference, ZEuP (2010)

4. Rösler, H.: Rechtswahl und optionales Vertragsrecht in der EU, EuZW (2011)

5. Schulte-Nölke, H.: The way forward in European consumer contract law: optional instrument instead of further deconstruction of national private laws. In: Twigg/Flesner, The Cambridge Companion to European Union Private Law (2010)

6. Tonner, K.: Das Grünbuch der Kommission zum Europäischen Vertragsrecht für Verbraucher und Unternehmer - Zur Rolle des Verbrauchervertragsrechts im europäischen Vertragsrecht, EuZW (2010)

\footnotetext{
${ }^{22}$ Lein, Issues of private international law, jurisdiction and enforcement of judgments linked with the adoption of an optional EU contract law, Workshop on an optional instrument for EU contract law, European Parliament, 27 October 2010.

${ }^{23}$ Regulation no 1896/2006 creating a European Order for Payment Procedure.

${ }^{24}$ Regulation no 861/2007 establishing a European Small Claims Procedure.

25 von Bar, What can we expect from an optional instrument?, ERA Conference 18-19 March 2010; Terryn, The Common Frame of Reference: an optional instrument, European Parliament, April 2010; Busch, Scope and content of an optional instrument for EU contract law, Workshop on an optional instrument for EU contract law, European Parliament, 27 October 2010; Herresthal [2], pp. 7, 10; Wallis, Draft Report of 25 January 2011, pp. 5, 9
} 